\title{
Relationship of four vitamin D receptor gene polymorphisms with type 1 diabetes mellitus susceptibility in Kuwaiti children
}

\author{
Majedah A. Rasoul ${ }^{1,2}$, Mohammad Z. Haider ${ }^{1 *}$ (D), Maria Al-Mahdi ${ }^{2}$, Hessa Al-Kandari, ${ }^{3,4}$ and Gursev S. Dhaunsi ${ }^{1,5}$
}

\begin{abstract}
Background: The incidence of type 1 diabetes mellitus (T1DM) in Kuwait is amongst the highest in the world. Vitamin $D$ is considered to be involved in immune modulation and its deficiency contribute to autoimmune destruction of insulin producing beta cells in T1DM patients. Vitamin D has been shown to exert its effects via a nuclear vitamin D receptor (VDR) and therefore, VDR gene may be considered a candidate for T1DM susceptibility.

Methods: The genotypes of four VDR gene polymorphisms were determined in 253 Kuwaiti Arab T1DM patients and 214 healthy controls by PCR-RFLP analysis. Serum concentrations of three autoantibodies i.e. ICA (Islet cell autoantibody), GADA (Glutamic acid decarboxylase) and INS (Insulin autoantibody) were determined by radioimmunoassays.
\end{abstract}

Results: Statistically significant differences were detected between the genotypes of two VDR gene polymorphisms (Fokl, C > T, rs10735810 and Taql, C> T, rs731236) between T1DM patients and controls $(P<0.0001)$. In both, the frequency of variant alleles was considerably high in T1DM than in the controls. In contrast, the VDR gene Apal ( $G>$ T, rs7975232) and Bsml (A > G, rs1544410) polymorphisms did not show association with T1DM. The homozygous variant genotypes of Fokl, Apal and Taql polymorphisms show significant differences between various age-of-onset subgroups while no such association was detected in the case of Bsml polymorphism. Significant differences were also noted between heterozygous genotypes of all four polymorphisms especially between 4-6y and > 6y age-of-onset subgroups of T1DM patients. Three autoantibodies, ICA (Islet cell), GADA (glutamate decarboxylase) and INS (insulin) were positively associated to, varying degrees, with T1DM in Kuwaiti Arabs harboring different VDR gene polymorphism genotypes.

Conclusions: Our results demonstrate a significant effect of two VDR gene polymorphisms (Fokl and Taql) and three autoantibodies on genetic susceptibility of T1DM in Kuwaiti Arabs along with other factors.

Keywords: Autoantibody, Genotype, Vitamin D receptor gene, Type 1 diabetes mellitus, Polymorphism, Kuwait

\section{Background}

Type 1 diabetes mellitus (T1DM) is a chronic multifactorial disease that is considered to be caused by selective autoimmune destruction of the pancreatic beta-cells which makes the affected individual dependent on exogenous insulin. Recent epidemiological data from Kuwait [1] showed a considerable increase in the incidence of T1DM (40.9 per 100,000) compared to 3.96 per 100,000 individuals

\footnotetext{
* Correspondence: haider@hsc.edu.kw

1 Department of Pediatrics, Faculty of Medicine, Kuwait University, P.O. Box 24923, Safat-13110 Jabriya, Kuwait

Full list of author information is available at the end of the article
}

reported in the 1980-81 [2]. This alarming increase in the T1DM incidence rate has moved Kuwait to the list of high-incidence countries. A wide variation in the incidence of T1DM has been reported across the globe with highest incidence found in Scandinavian countries and lowest in China and Japan [3]. It has been suggested that environmental factors, nutritional pattern, life style changes along with genetic susceptibility may be responsible for this wide variation and rapid increase in the incidence of T1DM in different world populations.

Several past reports have demonstrated that serum vitamin D deficiency is wide spread around the world 
[4-8]. It has been shown that the vitamin D deficiency is involved in induction of autoimmune destruction of beta-cells and onset of T1DM through the loss of immunomodulation (vitamin $\mathrm{D}$ favors Th2 response and protects from further beta-cell destruction $[9,10])$. There is also evidence which show that the risk of T1DM from vitamin D deficiency has increased over the years [11, 12]. It has been reported that vitamin D activates human macrophages, antigen presenting cell maturation, has a negative effect on dendritic cell differentiation and is involved in the regulation of cytokine production by interacting with immune cells and may therefore be considered an immune system modifier [13]. Also, it has been shown that the administration of vitamin $\mathrm{D}$ has a protective effect against T1DM in non-obese diabetic (NOD) mice [14]. Previous reports have shown that the dietary intake of vitamin D in early childhood decreased the risk of T1DM $[15,16]$. Also, the maternal vitamin $\mathrm{D}$ supplementation during pregnancy resulted in protection from appearance of islet cell autoantibodies in newborn babies [17]. Vitamin D exert its actions via a nuclear vitamin $\mathrm{D}$ receptor (VDR) therefore the $V D R$ gene can be considered a candidate/susceptibility gene for T1DM [18]. The VDR gene contain eight protein-encoding exons (exons 2-9) and six untranslated exons (exons 1a-1f), and is located on chromosome 12 [19]. The VDR belongs to the steroid receptor super-family and is expressed in many cell types which include lymphocytes, macrophages, and pancreatic cells [20]. A number of single nucleotide polymorphisms (SNPs) have been reported in the VDR gene; these include FokI, (rs10735810), ApaI (rs7975232), TaqI (rs731236) and BsmI (rs1544410) [18]. In the case of FokI, the presence of $\mathrm{T}$ creates an additional ATG initiation codon in exon 2, which result in VDR protein that is three amino acids longer. The ApaI and $B s m \mathrm{I}$ polymorphisms are located in intron 8 while the silent TaqI polymorphism is present in intron 9 [18]. It has been reported that the $V D R$ gene polymorphisms have been associated with altered gene expression or gene function [21]. These four $V D R$ gene polymorphisms have been studied in several different populations (including India, Japan, Iran and Finland) for their association with T1DM with inconsistent results [22-25]. A study from South India showed that b-allele of the VDR gene, BsmI polymorphism was associated with T1DM [22]. However, no association was detected between VDR gene polymorphisms and T1DM in patients from Finland [25]. Boraska et al. [26] reported an association of VDR gene Tru9I polymorphism and Tru9I-BsmI haplotypes with T1DM in patients from South Croatia. In contrast, no significant association between three $V D R$ gene polymorphisms (BsmI, ApaI and TaqI) and T1DM was detected in patients from Chile [27]. The data from Sudan, showed an association of two $V D R$ gene polymorphisms (BsmI and TaqI) with T1DM [28]. In a study from Pakistan, $V D R$ gene polymorphisms FokI and ApaI were found to be associated with T1DM while no association was found with the TaqI polymorphism [29]. A positive association between $V D R$ gene polymorphisms and T1DM has also been reported in Chinese Han population [30], in Taiwan [31], in Saudi Arabia [32], in Korea [33] and in Spain [34]. However, in contrast to these positive associations, a study from Denmark, reported no association between type 1 diabetes and genetic variation in vitamin D metabolism genes [35]. The relationship between inherited variation in vitamin $\mathrm{D}$ genes and diabetes has been addressed in recent reviews and meta-analyses [36-38]. In view of the divergent findings in different populations/ethnic groups, we determined the prevalence of four $V D R$ gene polymorphisms in Kuwaiti Arab children and investigated their correlation with age-of-onset of the disease in order to evaluate their influence on susceptibility to T1DM in a completely different population/ethnic group. In addition, we also determined the serum concentrations of three autoantibodies in Kuwaiti children with T1DM and explored their pattern of association with different $V D R$ gene polymorphism genotypes.

\section{Methods}

This study had a 'case-control' design and included 253 newly diagnosed T1DM patients from three major hospitals (Adan, Farwania and Mubarak Al-Kabeer). A large sub-set of T1DM patients from this report had been included in our earlier publications $[8,39]$. The diagnosis and inclusion criteria employed have been described earlier and were based on that recommended by the ISPAD protocol [40]. In order to investigate an association of $V D R$ gene polymorphisms with age of onset of T1DM, the patient group was divided into three sub-groups on the basis of age-of-onset of T1DM; 0-4y, 4-6y and 6-14y as reported earlier [41]. The age-of-onset subgrouping was modified slightly (instead of 5-9 y used in [41], we chose the 4-6y range due to a very high incidence of T1DM cases in earlier age in Kuwaitis. The glycemic status of study subjects was determined by measuring the serum levels of HbA1c by high performance liquid chromatography (HPLC). In addition to the T1DM patients, 214 non-diabetic healthy controls were also studied. The controls were volunteers, they can be considered as convenience samples, and were all Kuwaiti Nationals of similar ethnicity to the T1DM patients. The mean age in the T1DM patients group was 8.5 years $( \pm 5.5)$ compared to 8.9 years $( \pm 5.2)$ in the controls (no statistically significant difference between the two groups). In T1DM patients there were 125 males while the control group had 110 males $(P=0.5)$. The T1DM patients group contained 128 females compared to 104 in the controls $(P=0.51)$. 
The details of sample collection and processing have been described previously [8]. For determination of the $V D R$ genotypes, the blood was anti-coagulated with EDTA and the total genomic DNA was isolated by a standard method [42].

\section{VDR gene Fokl polymorphism}

The FokI polymorphism, C > T (rs10735810), in VDR gene was identified by using a polymerase chain reaction-restriction fragment length polymorphism (PCR-RFLP) method described earlier [43]. A 265 bp PCR product was amplified by using the primers: Forward: 5'-AGCTGGCCCTGGCACTGACTCTGCTCT-3' and Reverse: 5'-ATGGAAACACCTTGCTTCTTCTCCCT C-3 [43]. The PCR mixture contained 200 ng DNA template, $20 \mathrm{nmol}$ of each primer, $2.0 \mathrm{mM} \mathrm{MgCl}_{2}, 0.2 \mathrm{mM}$ $\mathrm{dNTPs}$ and 1.0U AmpliTaq DNA polymerase (Applied BioSystems). The PCR reactions were carried out at $94{ }^{\circ} \mathrm{C}$ for $5 \mathrm{~min}$ followed by 35 cycles of $94^{\circ} \mathrm{C}$ for $30 \mathrm{~s}, 60^{\circ} \mathrm{C}$ for $30 \mathrm{~s}$ and $72{ }^{\circ} \mathrm{C}$ for $30 \mathrm{~s}$ and an extension step of $72^{\circ} \mathrm{C}$ for $7 \mathrm{~min}$ [43]. The products of PCR amplification were cleaved with $10 \mathrm{U}$ of restriction enzyme FokI (New England BioLabs) at $37^{\circ} \mathrm{C}$ for $90 \mathrm{~min}$. The cleavage products were analyzed by agarose gel electrophoresis (2\%) and visualized by ethidium bromide staining under UV light. Alleles ' $F$ ' or ' $f$ ' were assigned on the basis of presence of $265 \mathrm{bp}$ fragment (f-allele) and 196 and $69 \mathrm{bp}$ products (F-allele) respectively. In heterozygous Ff individuals, products of 265, 196 and $69 \mathrm{bp}$ were present.

\section{VDR gene Apal and Taql polymorphisms}

The g.59979G > T (ApaI; rs7975232) and g.60058T > C (TaqI; rs731236) polymorphic sites of the $V D R$ gene were analyzed by PCR-RFLP method [44, 45]. A 740-bp fragment was amplified using the primers; Forward: 5'-CAGAGCATGGACAGGGAGCAAG-3' and Reverse: 5'-GCAACTCCTCATGGCTGAGGTCTCA-3' [44]. The PCR mixture contained $100 \mathrm{ng}$ DNA template, $20 \mathrm{nmol}$ of each primer, $2.2 \mathrm{mM} \mathrm{MgCl}_{2}, 0.2$ $\mathrm{mM}$ dNTPs and $0.8 \mathrm{U}$ AmpliTaq DNA polymerase (Applied BioSystems). The PCR conditions used were: $94{ }^{\circ} \mathrm{C}$ for $5 \mathrm{~min}$; 30 cycles consisting of $1 \mathrm{~min}$ at $94{ }^{\circ} \mathrm{C}$, $1 \mathrm{~min}$ at $60^{\circ} \mathrm{C}$ and $90 \mathrm{~s}$ at $72{ }^{\circ} \mathrm{C}$ followed by an extension step for $10 \mathrm{~min}$ at $72^{\circ} \mathrm{C}$. The PCR product was digested with $5 \mathrm{U}$ ApaI (New England BioLabs) at $25^{\circ} \mathrm{C}$ overnight. The products of restriction enzyme cleavage were separated by $2 \%$ agarose gel electrophoresis and were visualized under UV light after staining with Ethidium bromide. In the presence of T-allele, there was no restriction enzyme cleavage site and a product of $740 \mathrm{bp}$ was obtained. In subjects carrying 'G-allele', the cleavage products of 530- and 212-bp were detected.

The same PCR product was digested with restriction enzyme TaqI (New England BioLabs) at $65^{\circ} \mathrm{C}$ for $75 \mathrm{~min}$ to detect the TaqI polymorphism [44]. The products of restriction enzyme digestion were analyzed on $2 \%$ agarose gels and visualized under UV following staining with Ethidium bromide. Allele ' $\mathrm{T}$ ' was associated with the presence of $495 \mathrm{bp}$ and $245 \mathrm{bp}$ cleavage products while allele 'C' was assigned in the presence of 290, 245 and 210-bp fragments respectively [44, 45].

\section{VDR gene Bsml polymorphism ( $\mathrm{A}>\mathrm{G}, \mathrm{rs1544410)}$}

This polymorphism was determined according to a modification of the previously published PCR-RFLP method [44]. The PCR amplification was carried out by using the primers, Forward: 5'-AACCAGCGGGAAGA GGTCAAGGG-3' and Reverse: 5'-CAACCAAGA CTACAAGTACCGCGTCAGTGA-3' [44]. The PCR mixture contained $100 \mathrm{ng}$ DNA template, $20 \mathrm{nmol}$ of each primer, $1.5 \mathrm{mM} \mathrm{MgCl} 2,0.2 \mathrm{mM}$ dNTPs and $1.0 \mathrm{U}$ AmpliTaq DNA polymerase and the amplification conditions used were: $95^{\circ} \mathrm{C}$ for $5 \mathrm{~min}$; 30 cycles of $94{ }^{\circ} \mathrm{C}$ for 1 min, $57^{\circ} \mathrm{C}$ for $1 \mathrm{~min}, 72^{\circ} \mathrm{C}$ for $1 \mathrm{~min}$ followed by $10 \mathrm{~min}$ at $72{ }^{\circ} \mathrm{C}$. Using the above conditions and ingredients, PCR amplification resulted in $870 \mathrm{bp}$ PCR product. The PCR amplification products were cleaved with restriction enzyme MvaI (New England BioLabs) at $37^{\circ} \mathrm{C}$ for 75 min. The products of the restriction enzyme digestion were analyzed using $2 \%$ agarose gel electrophoresis and visualized by UV light following staining with Ethidium bromide. Allele 'B' was assigned based on the presence of $870 \mathrm{bp}$ (cleavage site absent) and allele 'b' was associated with the presence of products of 460, 234 and 176 bp respectively [44].

The haplotypes were built by using a previously published method [18] and were described in the order FokI/TaqI/ApaI/BsmI. The comparisons were made in the haplotype frequency between T1DM patients and the controls.

\section{Detection of autoantibodies}

The method used for detection of three autoantibodies (Islet Cell autoantibody, ICA; glutamic acid decarboxylase, GADA and Insulin, INS autoantibodies has been described in our earlier report [39]. For GADA and ICA autoantibodies, the cut off values used were 180 and 80 counts per minute/microliter of the sera respectively. The patients were divided into autoantibody-positive and autoantibody-negative sub-groups.

\section{Statistical analysis}

The data was analyzed by using the Statistical Package for Social Sciences version 25 (SPSS, Chicago IL, USA). Genotype and allele frequencies in T1DM patients and controls were calculated by direct counting. The continuous variables in the T1DM patient and control groups were compared using the student t-test. The 


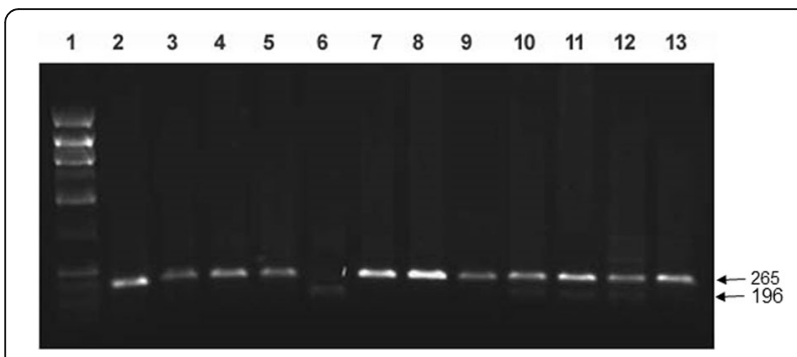

Fig. 1 Detection of VDR gene Fokl polymorphism. PCR amplification of the genomic DNA was carried out and the products of amplification were cleaved with restriction enzyme Fokl (details given in Methods). Lane 1, phiX174 Haelll cut $M_{r}$ markers; lane 2, uncleaved PCR product; lane 3-5,7-9 \& 13, PCR products from subjects having ff genotype; lane 6 , pattern from a subject with homozygous FF genotype; lanes 10-12, pattern from subjects with heterozygous $\mathrm{Ff}$ genotype. The numbers on the side are sizes (bp) of the characteristic bands resulting from PCR-RFLP analysis. The restriction enzyme cleavage products were analyzed on $2 \%$ agarose gel and visualized under UV light after staining with Ethidium bromide categorical variables were analyzed using the Chi-square and the Fisher's Exact test as appropriate. Odds ratios (OR) were calculated with 95\% confidence interval (CI). The data in the three age-of-onset subgroups were further analyzed by Chi-Square test and the Fisher's Exact test. The $P$-values $<0.05$ were considered as significant. In order to calculate the statistical significance in co-dominant and dominant models, the genotype frequency in homozygous FF subjects and frequency of ' $\mathrm{F}$ ' allele of the FokI polymorphism, homozygous TT and frequency of ' $\mathrm{T}$ ' allele of the TaqI polymorphism, genotype TT and allele $\mathrm{T}$ of the ApaI polymorphism and genotype $\mathrm{BB}$ and allele $\mathrm{B}$ of the Bsm $\mathrm{I}$ polymorphisms were considered as reference (assumed to be associated with the least risk of T1DM). In the dominant model, genotype frequencies of the heterozygous $\mathrm{Ff}$ and homozygous ff (for FokI polymorphism), heterozygous $\mathrm{Tt}$ and homozygous tt genotypes in the case of TaqI polymorphisms, heterozygous TG and homozygous GG in ApaI polymorphism and heterozygous $\mathrm{Bb}$ and homozygous $\mathrm{bb}$ for BsmI polymorphism were pooled (i.e. T1DM patients who had at least one presumed 'susceptibility' allele). A possible limitation of the study may be that the presence

Table 1 Comparison of the genotype and allele frequency of VDR gene polymorphisms (Fokl, and Taql) between Kuwaiti T1DM patients and controls

\begin{tabular}{|c|c|c|c|c|}
\hline VDR gene polymorphism & Patients N (\%) & Control $N^{*}(\%)$ & OR $(95 \% \mathrm{Cl})^{* *}$ & $P$-value $* * *$ \\
\hline \multicolumn{5}{|l|}{ Fokl } \\
\hline Co-dominant & $N=253$ & $N=214$ & & \\
\hline $\mathrm{FF}$ & $45(17.8)$ & $146(68.2)$ & 1.00 (Reference) $^{a}$ & \\
\hline $\mathrm{Ff}$ & $30(11.9)$ & $1(0.5)$ & $97.3(12.90-73.24)$ & $<0.0001$ \\
\hline ff & $178(70.3)$ & $67(31.3)$ & $8.62(5.57-13.35)$ & $<0.0001$ \\
\hline \multicolumn{5}{|l|}{ Dominant } \\
\hline $\mathrm{FF}$ & $45(17.8)$ & $146(68.2)$ & 1.00 (Reference) $^{a}$ & \\
\hline $\mathrm{Ff} / \mathrm{ff}(\mathrm{Ff}+\mathrm{ff})$ & $208(82.2)$ & $68(31.8)$ & $9.92(6.44-15.28)$ & $<0.0001$ \\
\hline Alleles & $N=506$ & $N=428$ & & \\
\hline $\mathrm{F}$ & $120(23.7)$ & $293(68.51)$ & 1.00 (Reference) $^{a}$ & \\
\hline$f$ & $386(76.3)$ & 135 (31.5) & $6.98(5.23-9.3)$ & $<0.0001$ \\
\hline Taql & $N=253$ & $N=214$ & & \\
\hline \multicolumn{5}{|l|}{ Co-dominant } \\
\hline$\pi$ & $96(38)$ & $156(73)$ & 1.00 (Reference) $^{a}$ & \\
\hline $\mathrm{TC}$ & $96(38)$ & $36(17)$ & $4.3(2.73-6.86)$ & $<0.0001$ \\
\hline $\mathrm{CC}$ & $61(24)$ & $22(10)$ & $4.51(2.60-7.81)$ & $<0.0001$ \\
\hline \multicolumn{5}{|l|}{ Dominant } \\
\hline$\pi$ & $96(38)$ & $156(73)$ & 1.00 (Reference) $^{\mathrm{a}}$ & \\
\hline $\mathrm{TC} / \mathrm{CC}(\mathrm{TC}+\mathrm{CC})$ & $157(76)$ & $58(27)$ & $4.39(2.96-6.52)$ & $<0.0001$ \\
\hline Alleles & $N=506$ & $N=428$ & & \\
\hline $\mathrm{T}$ & $288(56.9)$ & $348(81.3)$ & 1.00 (Reference) $^{\mathrm{a}}$ & \\
\hline C & $218(43.1)$ & 80 (18.9) & $3.29(2.44-4.45)$ & $<0.0001$ \\
\hline
\end{tabular}

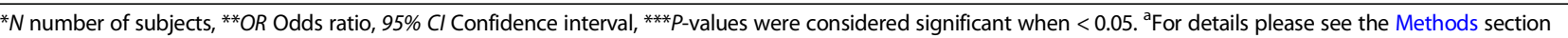


of low numbers in some comparisons e.g. age-of-onset in T1DM patients and with autoantibody-positivity, may result in type-II errors. Hardy Weinberg equilibrium was tested in the genotype distributions by goodness of fit method using MSTAT software.

\section{Results}

Amongst the T1DM patient group, 193/253 (76\%) had their HbA1c between 7 and 10\% and in 60/253 (24\%) it was $>10 \%$. In all controls, the HbA1c level was below $6.5 \%$. The mean serum vitamin $\mathrm{D}$ level in Kuwaiti T1DM patients was $12.88 \pm 6.66 \mathrm{ng} / \mathrm{ml}$ and in the controls it was $15.02 \pm 10.4 \mathrm{ng} / \mathrm{ml}$. The general characteristics of the T1DM patients and controls have been described in a recent report from our group [39]. An example of the method employed for detecting the $V D R$ gene FokI polymorphism and the results obtained have been presented in Fig. 1. Statistically significant differences were detected in the case of homozygous $\mathrm{ff}$ genotype and the ' $\mathrm{f}$ ' allele between T1DM patients and controls (OR 8.62; and 9.92 in co-dominant and dominant models respectively, Table 1 ). The frequency of variant ' $\mathrm{f}$ ' allele was found to be considerably higher in
T1DM patients while the ' $\mathrm{F}$ ' allele was more prevalent in the controls (Table 1).

The method used for determining the genotypes of $V D R$ gene TaqI polymorphism has been presented in Fig. 2. The frequency of homozygous variant 'CC' genotype was significantly higher in T1DM patients than in the controls (OR, 4.51 and 4.39 in co-dominant and dominant models respectively, Table 1). The same trend was manifested in the case of ' $\mathrm{C}$ ' allele frequency (OR, 3.29, Table 1).

An example of the method used to determine genotypes of $V D R$ gene ApaI polymorphism in Kuwaiti T1DM patients with different genotypes has been presented in Fig. 3. There was no significant difference between the frequencies of any of the genotype or allele between T1DM patients and the controls (Table 2). Although ApaI polymorphism was not informative in our cohort but like in many other populations, the ' $G$ ' allele was the 'minor allele' amongst Kuwaiti Arabs.

The genotype detection method used for $V D R$ gene $B s m I$ polymorphism has been presented in Fig. 4. No significant difference was detected in any of the three genotypes ( $\mathrm{bb}, \mathrm{Bb}$ and $\mathrm{BB}$ ) or the two alleles between

Table 2 Comparison of the genotype and allele frequency of VDR gene polymorphisms (Apal, and Bsml) between Kuwaiti T1DM patients and controls

\begin{tabular}{|c|c|c|c|c|}
\hline VDR gene polymorphism & Patients N (\%) & Control $N^{*}(\%)$ & OR $(95 \% \mathrm{Cl})^{* *}$ & $P$-value ${ }^{* * *}$ \\
\hline Apal & $N=252^{a}$ & $N=214$ & & \\
\hline \multicolumn{5}{|l|}{ Co-dominant } \\
\hline$\pi$ & $192(76.2)$ & $162(75.7)$ & 1.00 (Reference) & \\
\hline GT & $31(12.3)$ & $37(17.3)$ & $0.71(0.42-1.19)$ & 0.23 \\
\hline GG & $29(11.5)$ & $15(7.0)$ & $1.63((0.85-3.15)$ & 0.15 \\
\hline \multicolumn{5}{|l|}{ Dominant } \\
\hline$\pi$ & $192(76.2)$ & $162(75.7)$ & 1.00 (Reference) & \\
\hline $\mathrm{GT} / \mathrm{TT}(\mathrm{GT}+\mathrm{TT})$ & $60(23.8)$ & $52(24.3)$ & $0.97(0.64-1.49)$ & 0.99 \\
\hline Alleles & $N=504$ & $N=428$ & & \\
\hline T & $415(82.3)$ & $361(84.3)$ & 1.00 (Reference) & \\
\hline G & $89(17.7)$ & $67(15.7)$ & $1.16(0.82-1.64)$ & 0.47 \\
\hline \multicolumn{5}{|l|}{ Bsml } \\
\hline Co-dominant & $N=253$ & $N=214$ & & \\
\hline BB & $141(55.7)$ & $120(56.1)$ & 1.00 (Reference) & \\
\hline $\mathrm{Bb}$ & $83(32.8)$ & $66(30.8)$ & $1.07(0.71-1.60)$ & 0.82 \\
\hline $\mathrm{bb}$ & $29(11.5)$ & $28(13.1)$ & $0.88(0.50-1.56)$ & 0.78 \\
\hline \multicolumn{5}{|l|}{ Dominant } \\
\hline BB & $141(55.7)$ & $120(56.1)$ & 1.00 (Reference) & \\
\hline $\mathrm{Bb} / \mathrm{bb}(\mathrm{Bb}+\mathrm{bb})$ & $112(44.3)$ & $94(43.9)$ & $1.01(0.70-1.46)$ & 0.94 \\
\hline Alleles & $N=506$ & $N=428$ & & \\
\hline B & $365(72.1)$ & $306(71.5)$ & 1.00 (Reference) & \\
\hline$b$ & $141(27.9)$ & $122(28.5)$ & $0.97(0.73-1.29)$ & 0.88 \\
\hline
\end{tabular}




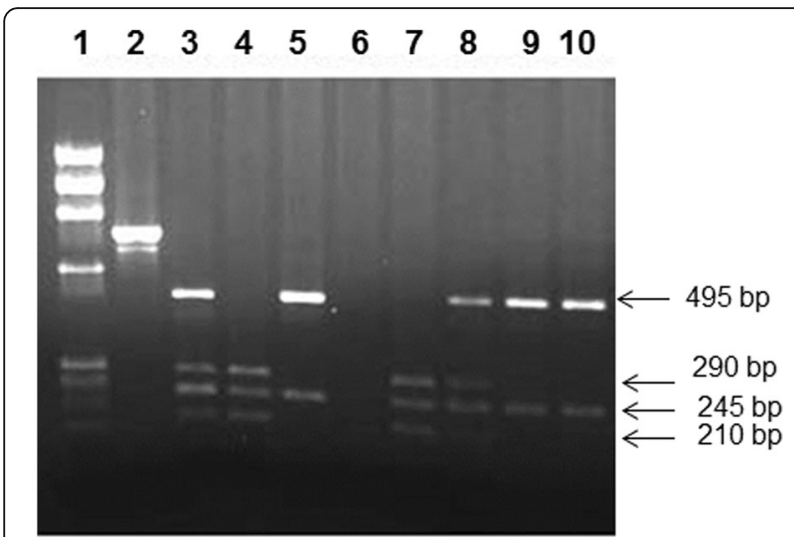

Fig. 2 Detection of VDR gene Taql polymorphism. PCR amplification of the genomic DNA was carried out and the products of amplification were cleaved with restriction enzyme Taql (details given in Methods). Lane 1, phiX174 Haelll cut $M_{r}$ markers; lane 2, uncleaved PCR product, lanes 3,8 Taql cleavage pattern from subjects with heterozygous TC genotype; lanes 4,7 Taql cleaved PCR product from subjects with CC genotype; lanes 5,9-10 Taql cleaved PCR products from a subject with $\pi$ genotype, lane 6 , no sample. The products were analyzed on $2 \%$ agarose gel and visualized under UV light after staining with ethidium bromide. The number on the right side indicate the product sizes (bp)

T1DM patients and the controls (Table 2). The data on genotype and allele frequency showed that minor allele in the cohort was ' $b$ ' but it did not show any significant difference between patient and the control groups suggesting that this polymorphism was not associated with T1DM in the Kuwaiti cohort studied.

\section{$\begin{array}{lllllllll}1 & 2 & 3 & 4 & 5 & 6 & 7 & 8 & 9\end{array}$}

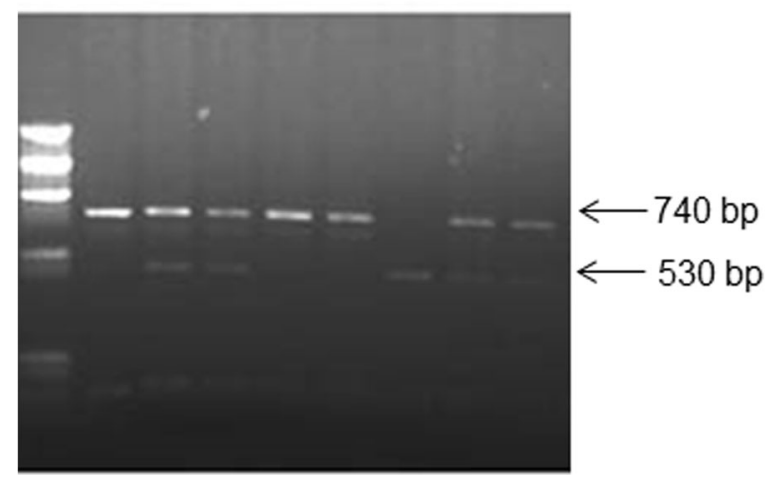

Fig. 3 Detection of VDR gene Apal polymorphism. PCR amplification of the genomic DNA was carried out and products of amplification were cleaved with restriction enzyme Apal (details given in Methods). Lane 1, phiX174 Haelll cut $M_{r}$ markers; lane 2, uncleaved PCR product; lanes $3,4,8,9$, products from subjects with heterozygous GT genotype; lanes 5-6, products from subjects with homozygous TT genotype; lane 7, products from homozygous GG genotype. The numbers on the side are sizes (bp) of the characteristic bands resulting from PCR-RFLP analysis. The cleavage products were analyzed on 2\% agarose gel and visualized under UV light after staining with Ethidium bromide
A comparison of the frequency of VDR gene FokI polymorphism genotypes between different age-of-onset subgroups of T1DM patients has been presented in Table 3. In Kuwaiti T1DM patients with FokI polymorphism genotypes ff and Ff (having at least one variant allele), statistically significant difference was detected between patients with age-of-onset $<4 y$ and those with $>6 y$ and between age-of-onset subgroups $4-6 y$ and $>6 y$ respectively (Table 3 ). In T1DM patients with ApaI genotypes GG and GT (having at least one variant allele), statistically significant difference was detected between patients with age-of-onset $<4 y$ and those with $>6 y$ and between subgroups 4-6y and >6y (Table 4). In T1DM patients who had CC genotype for TaqI polymorphism showed statistically significant difference between $<4 y$ and $>6 y$ subgroups and none of the other subgroups (Table 5). However, the heterozygous CT genotype showed statistically significant difference between patients with age-of-onset $<4 y$ and those with $>6 y$ and between subgroups 4-6y and >6y (Table 5). In T1DM patients with BsmI genotype bb, no significant difference was detected between any of the subgroups and for heterozygous $\mathrm{Bb}$ statistically significant difference was detected between patients with age-of-onset $<4 y$ and those with $>6 y$ and between subgroups 4-6y and $>6 y$ respectively (Table 6). Even in the case of homozygous 'common' genotypes (FF, $\mathrm{TT}$, TT and $\mathrm{BB}$ ), of the VDR gene polymorphisms, significant differences were noted between some age-of-onset subgroups (Tables 3, 4, 5, and 6).

The allele frequencies from four VDR gene polymorphisms were used to build haplotypes as described earlier (18). Based on this scheme, fifteen haplotypes were constructed from the data obtained in Kuwaiti T1DM patients and controls. The frequency of each of these haplotype from T1DM patients and controls has been presented in Table 7 . Of the total fifteen haplotypes, significant differences were detected between the controls and T1DM patients in seven haplotypes (Table 7). From these seven haplotypes, the highest OR were detected in two haplotypes, $[\mathrm{f} / \mathrm{C} / \mathrm{T} / \mathrm{b}] P<0.002$ and $[\mathrm{f} / \mathrm{C} / \mathrm{T} / \mathrm{B}]$ $P<0.0001$ (Table 7). The frequency of both these haplotypes was considerably higher in T1DM patients than in the controls and collectively, these two haplotypes were detected in nearly $34 \%$ of all the Kuwaiti T1DM patients. This further highlighted the positive association of variant alleles (f) of the VDR gene FokI and TaqI polymorphisms with genetic predisposition of T1DM in Kuwaiti Arab children.

The frequency of positivity for three autoantibodies (ICA, GADA and INS) was determined in T1DM patients with different genotypes of four $V D R$ gene polymorphisms and has been presented in Table 8. In the case of ICA, the frequency of autoantibody-positivity 

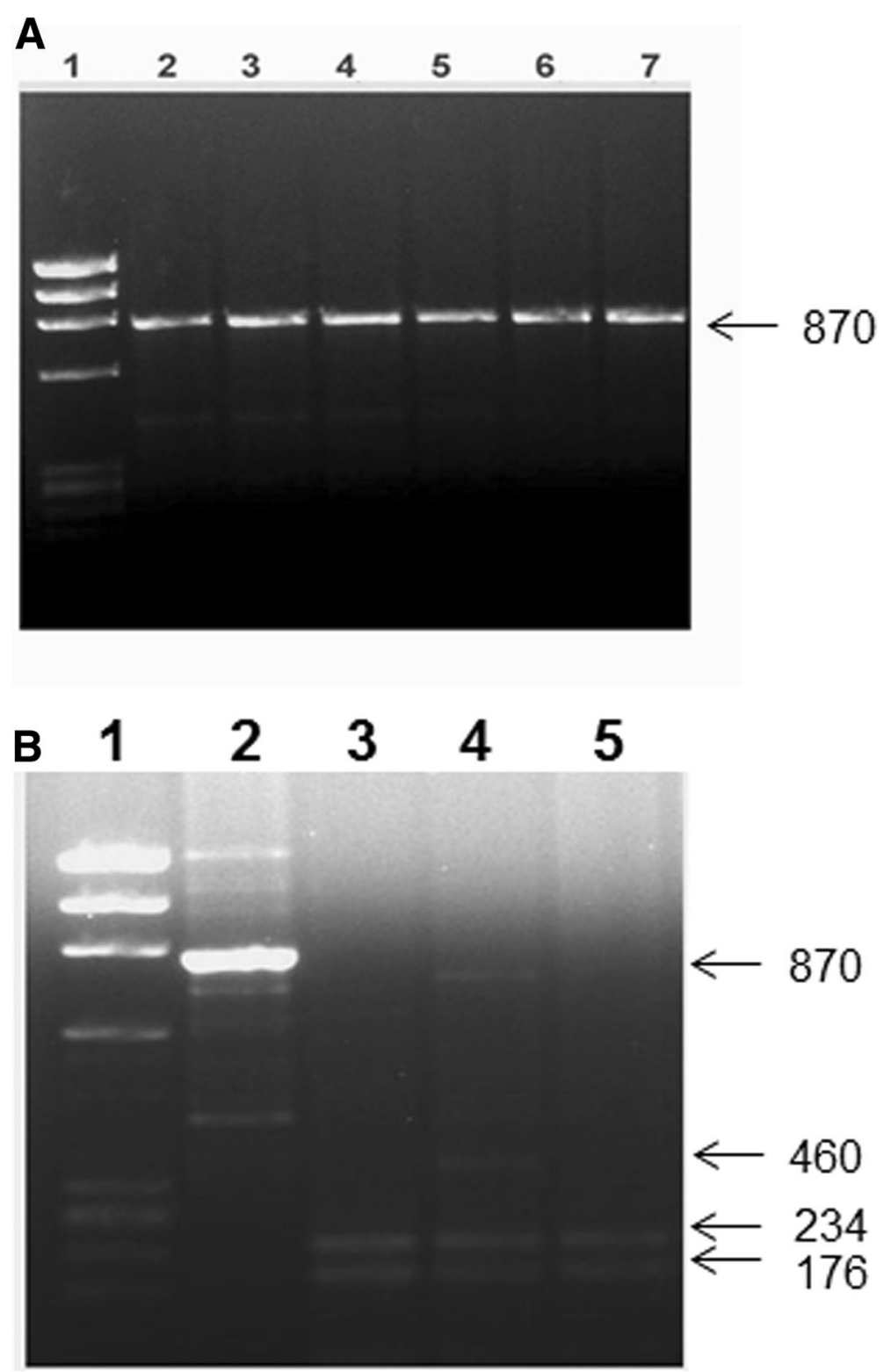

Fig. 4 Detection of VDR gene Bsml polymorphism. PCR amplification of genomic DNA was carried out and the products of amplification were cleaved with restriction enzyme Mval (details given in Methods). A: lane 1, phiX174 Haelll cut $M_{r}$ markers; lane 2, uncleaved PCR product; lanes 3-7, cleavage products from subjects with BB genotype. B: lane 1, X174 Haelll cut $M_{r}$ markers; lane 2, uncleaved PCR product; lane 3,5, cleavage products from subjects with bb genotype; lanes 4, cleavage products from subjects having Bb genotype. The numbers on the side are sizes (bp) of the characteristic bands resulting from PCR-RFLP analysis of the subjects having different genotypes. The restriction enzyme cleavage products were analyzed on 2\% agarose gel and visualized under UV light after staining with Ethidium bromide

was detected in approximately $48-66 \%$ of the T1DM patients (Table 8). The GADA-positivity was found in nearly 75-89\% T1DM patients carrying different VDR gene polymorphism genotypes (Table 8). The INS-positivity was observed in approximately $65-79 \%$ of the T1DM patients having different $V D R$ gene polymorphism genotypes (Table 8 ). Nearly all the T1DM patients harbored multiple autoantibodies (data not shown).

\section{Discussion}

This study investigated an association of four $V D R$ gene polymorphisms with susceptibility of T1DM in Kuwaiti Arabs by comparing the genotype frequencies between patients and the controls. A statistically significant association was detected between VDR gene FokI polymorphism and T1DM in Kuwaiti Arab children (Table 1). The FokI 'f' polymorphism results from a $\mathrm{C} \rightarrow \mathrm{T}$ transition at the junction of intron 1 and exon 2 
Table 3 Comparison of the genotype frequency of VDR gene Fokl polymorphism among different age-of-onset subgroups of Kuwaiti T1DM patients

\begin{tabular}{|c|c|c|c|}
\hline $\begin{array}{l}\text { Fokl Genotype/Age of } \\
\text { onset sub-groups }\end{array}$ & Frequency (\%) & OR $(95 \% \mathrm{Cl})^{*}$ & $P$-value** \\
\hline \multicolumn{4}{|l|}{ ff-genotype } \\
\hline$<4$ years vs & $33 / 174$ (19.0) & $0.74(0.44-1.23)$ & 0.30 \\
\hline $4-6$ years & $42 / 174(24.1)$ & & \\
\hline$<4$ years vs & 33/174 (19.0) & $0.18(0.11-0.29)$ & $<0.0001$ \\
\hline$>6$ years & 99/174 (56.9) & & \\
\hline $4-6$ years vs & $42 / 174(24.1)$ & $0.24(0.15-0.38)$ & $<0.0001$ \\
\hline$>6$ years & 99/174 (56.9) & & \\
\hline \multicolumn{4}{|l|}{ Ff-genotype } \\
\hline$<4$ years vs & $7 / 30(23.3)$ & $1.0(0.30-3.30)$ & 1 \\
\hline 4-6 years & $7 / 30(23.3)$ & & \\
\hline$<4$ years vs & $7 / 30(23.3)$ & $0.27(0.09-0.80)$ & 0.03 \\
\hline$>6$ years & 16/30 (53.4) & & \\
\hline $4-6$ years vs & $7 / 30(23.3)$ & $0.27(0.09-0.80)$ & 0.03 \\
\hline$>6$ years & 16/30 (53.4) & & \\
\hline \multicolumn{4}{|l|}{ FF-genotype } \\
\hline$<4$ years vs & $8 / 44(18.2)$ & $0.48(0.18-1.29)$ & 0.21 \\
\hline 4-6 years & 14/44 (31.8) & & \\
\hline$<4$ years vs & $8 / 44(18.2)$ & $0.22(0.08-0.58)$ & $<0.01$ \\
\hline$>6$ years & 22/44 (50.0) & & \\
\hline $4-6$ years vs & 14/44 (31.8) & $0.47(0.20-1.11)$ & 0.13 \\
\hline$>6$ years & 22/44 (50.0) & & \\
\hline
\end{tabular}

*OR $(95 \% \mathrm{Cl})$, odds ratio $95 \%$ confidence interval; ${ }^{*} P$-values were considered significant when $<0.05$. The age-of-onset information was not available in 5 T1DM patients (data reported from 248 T1DM patients)

and creates an additional initiation codon (ATG) located three codons downstream to the original start site [43]. The shorter VDR protein (424 aa, which results from FF genotype) is more active than the longer form (427 aa produced from ff-genotype [46]. Previous studies have demonstrated that the proportion of $\mathrm{CD}^{+}$cells was considerably lower in Th-cells (under vitamin D stimulation) from T1DM patients carrying the FF genotype compared to patients with Ff or ff genotypes [47]. It has been postulated that since the f-allele corresponds to a less active VDR protein [48, 49], the ff-genotype can possibly contribute to the development of T1DM either by causing weaker insulin production or by affecting vitamin D's immunosuppressive properties [50, 51]. A study from Brazil has reported that individuals with $\mathrm{ff}$ and Ff genotypes tended to have lower residual pancreatic beta-cell function [52]. Findings similar to our results from Kuwaiti Arabs have been reported from Egypt, where a significantly higher frequency of genotype $\mathrm{Ff}$ of the FokI polymorphism was found in T1DM patients compared to the controls [53]. However, in
Table 4 Comparison of the frequency of VDR gene Apal polymorphism genotypes among different age-of-onset sub-groups of Kuwaiti TIDM patients

\begin{tabular}{|c|c|c|c|}
\hline $\begin{array}{l}\text { Apal Genotype/Age of } \\
\text { onset sub-groups }\end{array}$ & Frequency (\%) & OR $(95 \% \mathrm{Cl})^{*}$ & $P$-value ${ }^{* *}$ \\
\hline \multicolumn{4}{|l|}{ GG-genotype } \\
\hline$<4$ years vs & $7 / 28(25)$ & $1.53(0.42-5.57)$ & 0.74 \\
\hline 4-6 years & $5 / 28(18)$ & & \\
\hline$<4$ years vs & $7 / 28(25)$ & $0.25(0.08-0.77)$ & 0.02 \\
\hline$>6$ years & $16 / 28(57)$ & & \\
\hline $4-6$ years vs & $5 / 28(18)$ & $0.16(0.04-0.55)$ & 0.005 \\
\hline$>6$ years & $16 / 28(57)$ & & \\
\hline \multicolumn{4}{|l|}{ GT-genotype } \\
\hline$<4$ years vs & 7/31 (22.6) & $1.22(0.36-4.14)$ & 1.0 \\
\hline 4-6 years & 6/31 (19.4) & & \\
\hline$<4$ years vs & $7 / 31(22.6)$ & $0.21(0.07-0.64)$ & $<0.01$ \\
\hline$>6$ years & 18/31 (58.0) & & \\
\hline $4-6$ years vs & 6/31 (19.4) & $0.17(0.06-0.54)$ & $<0.01$ \\
\hline$>6$ years & 18/31 (58.0) & & \\
\hline \multicolumn{4}{|l|}{ TT-genotype } \\
\hline$<4$ years vs & $34 / 188$ (18.0) & $0.58(0.35-0.94)$ & 0.04 \\
\hline 4-6 years & $52 / 188(27.7)$ & & \\
\hline$<4$ years vs & 34/188 (18.0) & $0.19(0.12-0.30)$ & $<0.0001$ \\
\hline$>6$ years & 102/188 (54.3) & & \\
\hline $4-6$ years vs & $52 / 188(27.7)$ & $0.32(0.21-0.50)$ & $<0.0001$ \\
\hline$>6$ years & $102 / 188(54.3)$ & & \\
\hline
\end{tabular}

*OR $(95 \% \mathrm{Cl})$, odds ratio $95 \%$ confidence interval; ${ }^{*} P$-values were considered significant when $<0.05$. The age-of-onset information was not available in 5 T1DM patients (data available from 248 T1DM patients). In one T1DM patient the Apal genotype could not be determined, therefore data reported from 247 cases

contrast to the Egyptian data, where the FokI and BsmI polymorphisms were correlated with T1DM, our result did not find any significant association between BsmI polymorphism and the T1DM in Kuwaiti Arab children. The results on haplotypes constructed from the genotype frequencies observed in Kuwaiti T1DM patients (Table 7) further support a significant correlation of the $V D R$ gene FokI and TaqI polymorphisms with susceptibility to T1DM.

In contrast to the FokI polymorphism which has functional implications, the ApaI, TaqI and BsmI polymorphisms are located near 3'end of the $V D R$ gene. Our results from Kuwaiti Arab children showed a positive association between the C-allele of VDR gene TaqI polymorphism and T1DM while no association was found between T1DM and the ApaI and BsmI polymorphisms. Similar results have been reported from Korean T1DM patients, in which TT genotype of the TaqI polymorphism was shown to have decreased risk compared to the homozygous $\mathrm{CC}$ and heterozygous TC genotypes 
Table 5 Comparison of the frequency of VDR gene Taql polymorphism genotypes among different age-of-onset sub-groups of Kuwaiti TIDM patients

\begin{tabular}{|c|c|c|c|}
\hline $\begin{array}{l}\text { Taql genotype/Age of } \\
\text { onset sub-groups }\end{array}$ & Frequency (\%) & OR $(95 \% \mathrm{Cl})^{*}$ & $P$-value** \\
\hline \multicolumn{4}{|l|}{ CC-genotype } \\
\hline$<4$ years vs & 11/60 (18.3) & $0.39(0.17-0.90)$ & 0.04 \\
\hline 4-6 years & $22 / 60(36.7)$ & & \\
\hline$<4$ years vs & 11/60 (18.3) & $0.27(0.12-0.63)$ & $<0.01$ \\
\hline$>6$ years & $27 / 60(45.0)$ & & \\
\hline $4-6$ years vs & 22/60 (36.7) & $0.71(0.34-1.47)$ & 0.46 \\
\hline$>6$ years & $27 / 60(45.0)$ & & \\
\hline \multicolumn{4}{|l|}{ CT-genotype } \\
\hline$<4$ years vs & 22/96 (22.9) & $1.29(0.64-2.59)$ & 0.59 \\
\hline 4-6 years & 18/96 (18.8) & & \\
\hline$<4$ years vs & 22/96 (24.5) & $0.21(0.11-0.40)$ & $<0.0001$ \\
\hline$>6$ years & 56/96 (58.3) & & \\
\hline $4-6$ years vs & 18/96 (18.8) & $0.16(0.09-0.32)$ & $<0.0001$ \\
\hline$>6$ years & $56 / 96(58.3)$ & & \\
\hline \multicolumn{4}{|l|}{ TT-genotype } \\
\hline$<4$ years vs & 15/92 (16.3) & $0.58(0.28-1.20)$ & 0.20 \\
\hline 4-6 years & 23/92 (25.0) & & \\
\hline$<4$ years vs & 15/92 (16.3) & $0.14(0.07-0.27)$ & $<0.0001$ \\
\hline$>6$ years & 54/92 (58.7) & & \\
\hline $4-6$ years vs & 23/92 (25.0) & $0.23(0.13-0.44)$ & $<0.0001$ \\
\hline$>6$ years & $54 / 92(58.7)$ & & \\
\hline
\end{tabular}

*OR $(95 \% \mathrm{Cl})$, odds ratio $95 \%$ confidence interval; ${ }^{* *} P$-values were considered significant when $<0.05$. The age-of-onset information was not available in 5 T1DM patients (data reported from 248 T1DM patients)

[32]. In contrast to the positive associations with TaqI $\mathrm{C}$-allele from Kuwait and Korea, the results reported from Germany, showed that frequency of TT genotype of $V D R$ gene TaqI polymorphism was higher in T1DM patients than in the controls [54]. The three VDR gene polymorphisms, ApaI, TaqI and BsmI have been shown to be in strong linkage disequilibrium with each other in the Caucasians but no significant linkage disequilibrium was reported with the FokI polymorphism [55]. The data reported here from Kuwaiti Arabs is markedly different from that in the Caucasians because the association with T1DM was detected only in the case of TaqI polymorphism. In a meta-analysis involving Chinese adult samples, it was concluded that possession of VDR gene BsmI polymorphism would increase the risk of T1DM in Asians, South Americans, Africans and Turks [37]. As stated earlier, the three polymorphisms i.e. ApaI, TaqI and $B s m I$ are located at the $3^{\prime}$ untranslated region (3'UTR) of the VDR gene [48]. The 3'UTR is known to be involved in regulation of gene expression, possibly through the control of mRNA stability $[44,56,57]$. Our
Table 6 Comparison of the frequency of VDR gene Bsml polymorphism genotypes among different age-of-onset sub-groups of Kuwaiti TIDM patients

\begin{tabular}{|c|c|c|c|}
\hline $\begin{array}{l}\text { Bsml genotype/Age of } \\
\text { onset sub-groups }\end{array}$ & Frequency (\%) & OR $(95 \% \mathrm{Cl})^{*}$ & $P$-value ${ }^{* *}$ \\
\hline \multicolumn{4}{|l|}{ bb - genotype } \\
\hline$<4$ years vs & $7 / 29(24.1)$ & $0.84(0.26-2.71)$ & 1.0 \\
\hline $4-6$ years & $8 / 29(27.6)$ & & \\
\hline$<4$ years vs & $7 / 29(24.1)$ & $0.34(0.11-1.05)$ & 0.10 \\
\hline$>6$ years & $14 / 29(48.3)$ & & \\
\hline $4-6$ years vs & $8 / 29$ (27.6) & $0.41(0.14-1.22)$ & 0.18 \\
\hline$>6$ years & $14 / 29(48.3)$ & & \\
\hline \multicolumn{4}{|l|}{ Bb-genotype } \\
\hline$<4$ years vs & 17/83 (20.5) & $0.87(0.41-1.82)$ & 0.85 \\
\hline 4-6 years & 19/83 (22.9) & & \\
\hline$<4$ years vs & 17/83 (20.5) & $0.20(0.10-0.39)$ & $<0.0001$ \\
\hline$>6$ years & 47/83 (56.6) & & \\
\hline $4-6$ years vs & 19/83 (22.9) & $0.23(0.12-0.45)$ & $<0.0001$ \\
\hline$>6$ years & 47/83 (56.6) & & \\
\hline \multicolumn{4}{|l|}{ BB-genotype } \\
\hline$<4$ years vs & 24/136 (17.6) & $0.60(0.33-1.07)$ & 0.11 \\
\hline $4-6$ years & $36 / 136$ (26.5) & & \\
\hline$<4$ years vs & 24/136 (17.6) & $0.17(0.20-0.30)$ & $<0.0001$ \\
\hline$>6$ years & 76/136 (55.9) & & \\
\hline $4-6$ years vs & $36 / 136$ (26.5) & $0.28(0.17-0.47)$ & $<0.0001$ \\
\hline$>6$ years & 76/136 (55.9) & & \\
\hline
\end{tabular}

*OR $(95 \% \mathrm{Cl})$, odds ratio $95 \%$ confidence interval; ${ }^{*} P$-values were considered significant when $<0.05$. The age-of-onset information was not available in 5 T1DM patients (data reported from 248 T1DM patients)

results from Kuwaiti Arab children and those reported from other populations (mentioned above), highlight the presence of a population-specific pattern of T1DM susceptibility which most likely result from an interaction of diverse and unique genetic factors with the environmental determinants that might exist in different geographical regions.

The pattern of association between VDR gene polymorphism genotypes and age-of-onset subgroups of Kuwaiti T1DM patients showed almost a similar pattern except for the BsmI polymorphism (Tables 3, 4, 5 and 6), mostly significant differences were detected between subgroups $<4 \mathrm{y}$ and $>6 \mathrm{y}$ and between 4-6y and $>6 \mathrm{y}$ subgroups. This is in contrast to the data reported from Brazil in which no association was found between the onset of T1DM and age at diagnosis [58]. A study from Japan showed a significantly high association between $V D R$ gene BsmI polymorphism allele $\mathrm{B}$ and the acute-onset type 1 diabetes [59]. It has been suggested that the variability in association of the VDR gene polymorphisms with T1DM in different populations may 
Table 7 Comparison of VDR gene haplotype frequencies in Kuwaiti T1DM patients and controls

\begin{tabular}{|c|c|c|c|c|}
\hline Haplotype $^{a}$ & Patients (\%) N=202 & Controls (\%) $N=154$ & Odds ratio $(95 \% \mathrm{Cl})^{*}$ & $P$-value ${ }^{* *}$ \\
\hline $\mathrm{f} / \mathrm{C} / \mathrm{G} / \mathrm{b}$ & $6(3)$ & 0 & $10.22(0.571-182.97)$ & 0.038 \\
\hline $\mathrm{f} / \mathrm{C} / \mathrm{G} / \mathrm{B}$ & $5(2.5)$ & $1(0.6)$ & $3.88(0.448-33.603)$ & 0.24 \\
\hline $\mathrm{F} / \mathrm{C} / \mathrm{G} / \mathrm{B}$ & $1(0.5)$ & $2(1.3)$ & $0.38(0.034-4.211)$ & 0.58 \\
\hline $\mathrm{f} / \mathrm{T} / \mathrm{G} / \mathrm{b}$ & $5(2.5)$ & $6(3.9)$ & $0.63(0.187-2.091)$ & 0.54 \\
\hline $\mathrm{F} / \mathrm{T} / \mathrm{G} / \mathrm{b}$ & 0 & $2(1.3)$ & $0.15(0.007-3.163)$ & 0.18 \\
\hline $\mathrm{f} / \mathrm{T} / \mathrm{GB}$ & $6(3)$ & $16(10.4)$ & $0.26(0.100-0.69)$ & 0.006 \\
\hline $\mathrm{F} / \mathrm{T} / \mathrm{G} / \mathrm{B}$ & $2(1)$ & $7(4.5)$ & $0.21(0.043-1.03)$ & 0.04 \\
\hline$f / C / T / b$ & $23(11.4)$ & $4(2.6)$ & $4.81(1.630-14.245)$ & $0.002^{\mathrm{b}}$ \\
\hline $\mathrm{F} / \mathrm{C} / \mathrm{T} / \mathrm{b}$ & $8(4)$ & $10(6.5)$ & $0.59(0.228-1.543)$ & 0.33 \\
\hline$f / C / T / B$ & $45(22.3)$ & $6(3.9)$ & $7.07(2.929-17.065)$ & $<0.0001^{b}$ \\
\hline $\mathrm{F} / \mathrm{C} / \mathrm{T} / \mathrm{B}$ & $14(6.9)$ & $14(9.1)$ & $0.75(0.345-1.613)$ & 0.58 \\
\hline$f / T / T / b$ & $20(9.9)$ & $14(9.1)$ & $1.10(0.536-2.253)$ & 0.93 \\
\hline $\mathrm{F} / \mathrm{T} / \mathrm{T} / \mathrm{b}$ & $6(3)$ & $20(13)$ & $0.21(0.080-0.524)$ & 0.0004 \\
\hline$f / T / T / B$ & $48(23.8)$ & $25(16.2)$ & $1.61(0.939-2.752)$ & 0.11 \\
\hline $\mathrm{F} / \mathrm{T} / \mathrm{T} / \mathrm{B}$ & $13(6.4)$ & $27(17.5)$ & $0.32(0.161-0.651)$ & 0.002 \\
\hline
\end{tabular}

${ }^{a}$ The VDR gene haplotypes were documented as described earlier [18] and the haplotypes were described in the order Fokl/Taql/Apal/Bsml; ${ }^{\mathrm{b}}$ The haplotypes containing majority of variant alleles and with highest OR are shown in bold. ${ }^{*} \mathrm{OR}(95 \% \mathrm{Cl})$, Odds ratio at $95 \%$ Confidence interval; * $P$-values were considered significant when $<0.05$

Table 8 Association of VDR gene polymorphisms (Fokl, Taql, Bsml and Apal) genotypes with three autoantibodies, ICA (islet cell autoantibody), GADA (glutamic acid decarboxylase) and INS (insulin autoantibody) in Kuwaiti T1DM patients

\begin{tabular}{clll}
\hline Genotype & ICA $+\mathrm{ve}^{*}(\%)$ & $\mathrm{GADA}+\mathrm{ve}^{*}(\%)$ & INS $+\mathrm{ve}^{*}(\%)$ \\
\hline Fokl & & & \\
$\mathrm{ff}$ & $101 / 178(57)$ & $146 / 178(82)$ & $126 / 178(71)$ \\
$\mathrm{Ff}$ & $16 / 30(53)$ & $26 / 30(87)$ & $21 / 30(70)$ \\
$\mathrm{FF}$ & $25 / 45(57)$ & $37 / 45(82)$ & $30 / 45(68)$ \\
Taql & & & \\
CC & $35 / 61(57)$ & $52 / 61(85)$ & $43 / 61(71)$ \\
TC & $53 / 96(55)$ & $85 / 96(89)$ & $70 / 96(73)$ \\
TT & $54 / 96(56)$ & $72 / 96(75)$ & $64 / 96(67)$ \\
Bsml & & & \\
bb & $19 / 29(66)$ & $24 / 29(83)$ & $23 / 29(79)$ \\
Bb & $46 / 83(55)$ & $72 / 83(87)$ & $54 / 83(65)$ \\
BB & $77 / 141(55)$ & $113 / 141(80)$ & $100 / 141(71)$ \\
Apal ${ }^{* *}$ & & & \\
GG & $14 / 29(48)$ & $23 / 29(79)$ & $21 / 29(72)$ \\
TG & $19 / 31(61)$ & $26 / 31(84)$ & $133 / 192(69)$ \\
TT & $109 / 192(57)$ & $159 / 192(83)$ &
\end{tabular}

*The positivity of autoantibodies was expressed as percentage of subjects carrying a specific autoantibody in comparison to the total number with a particular VDR genotype. Each patient carried multiple autoantibodies. ${ }^{*}$ In one T1DM patient, the genotype for Apal, could not be determined possibly be due to differences in their ethnic background, diverse evolutionary lineages, and interactions with other genetic and/or environmental factors which influence the pathogenesis of T1DM $[24,55]$.

The pattern of autoantibody-positivity was also analyzed in Kuwaiti T1DM patients harboring different genotypes of four $V D R$ gene polymorphisms (Table 8). A similar distribution pattern $(50-85 \%$ positivity) was observed amongst different $V D R$ genotypes with the highest positive correlation in the case of GADA autoantibody. This is markedly different from a previous study from Japan in which no association was found between GADA and IA-2 autoantibodies and the acute-onset type 1 diabetes [31, 59]. Several previous reports have described the autoantibodies to pancreatic antigens as a characteristic feature of T1DM [59]. The autoantibody association data with T1DM from India showed a relatively lower positive correlation between T1DM and three autoantibodies (GADA, ZnT8 and IA-2) [60]. Only $47 \%$ of the Indian T1DM patients carried one or more of these autoantibodies and highest positive correlation was seen with GADA (detected in $38 \%$ T1DM patients) [60]. In reports from Western populations, $85-90 \%$ of the newly diagnosed T1DM patients were shown to carry either GADA, IA-2, ZnT8 or INS autoantibody [61-64]. A higher incidence of GADA-positivity (73\%), followed by ICA-2 (42\%) has been reported from Saudi Arabia [65]. In contrast, GADA-positivity was reported in only $31 \%$ of the T1DM patients from China [66]. In comparison to previous reports from Asia, our findings from Kuwaiti T1DM 
patients showed a relatively higher positivity rate of GADA and INS autoantibodies. The GADA autoantibodies were detected in $>80 \%$ and the INS autoantibodies in $>70 \%$ Kuwaiti T1DM patients (Table 8 ). The autoantibody positivity in Kuwaiti T1DM patients who carried the variant genotypes of $V D R$ gene FokI and TaqI polymorphisms was slightly higher than that of the non-variant genotypes. Another significant feature of our results from Kuwaiti T1DM patients was that multiple autoantibodies were detected in each patient. The results reported here on VDR gene FokI and TaqI polymorphisms and autoantibodies along with those reported earlier [39] contribute significantly in identifying the determinants of genetic predisposition to T1DM in Kuwaiti Arab children.

\section{Conclusions}

The findings reported in this study show that the VDR gene FokI and TaqI polymorphisms are associated with susceptibility to T1DM in Kuwaiti Arabs. The $V D R$ gene polymorphisms ApaI and BsmI did not show a positive association with T1DM. However, the frequency of all four $V D R$ gene polymorphisms was higher in the late age-of-onset T1DM patients compared to the early age-of-onset cases from Kuwait. Three autoantibodies (ICA, GADA and INS) showed varying degree of positive association in T1DM patients carrying different genotypes of four $V D R$ gene polymorphisms with the highest positivity observed in the case of GADA autoantibody. The VDR gene polymorphisms (FokI and TaqI) and three autoantibodies contribute significantly to the genetic predisposition of T1DM Kuwaiti Arabs.

\footnotetext{
Abbreviations

bp: Base pair; CD4 + : Cluster of differentiation 4; Cl: Confidence interval; EDTA: Ethylene diamine tetra acetic acid; GADA: Glutamic acid decarboxylase 65KDa autoantibody; HbA1c: Glycated hemoglobin; HPLC: High performance liquid chromatography; ICA: Islet-cell autoantibody; INS: Insulin autoantibody; ISPAD: International Society of Pediatric and Adolescent Diabetes; NOD: Nonobese diabetic mouse; OR: Odds ratio; PCR-RFLP: Polymerase chain reaction-restriction fragment length polymorphism; SNP: Single nucleotide polymorphism; SPSS: Statistical package for social sciences, $M_{r}$ molecular size marker; T1DM: Type 1 diabetes mellitus; Th2: T helper cell type 2;

UV: Ultraviolet light; VDR: Vitamin D receptor
}

\section{Acknowledgements}

We thank Shilpa Mathews, Jalaja Sukumaran and Simranbir Kaur for technical assistance and Asiya Ibrahim for her help in statistical analysis. We also thank the study subjects for their participation and the hospital staff for their assistance.

\section{Ethical approval and consent to participate}

The study received approval by the Joint Committee for the Protection of Human subjects in Research (\# VDR/JC/116, dated November 3, 2011 and 2015) by the Kuwait University, Faculty of Medicine and Kuwait Institute of Medical Specializations. The research has been conducted strictly as per guidelines of the Joint Committee and according to the Helsinki Declaration. Written informed consent was obtained from the participants and/or their parents/guardians according to rules of the Ethics Committee.

\section{Funding}

The research was funded by Kuwait University (Project No. MK01/11). The funding body did not have any role in the design of the study, data analysis and manuscript writing.

\section{Availability of data and materials}

The data will not be made available in order to protect the participant's identity.

\section{Author's contributions}

Conceptualization: MZH, MAR. Data curation: MZH. Formal analysis: MZH, MA MAR. Funding acquisition: MZH, MAR. Investigation: MAR, MZH, MA, HA, GSD. Methodology: MAR, MZH, MA, HA, GSD. Resources: MA, HA, MAR.

Supervision: MZH. Writing - original draft: MZH. Writing - review and editing: MAR. All authors read and approved the manuscript.

\section{Consent for publication}

Not applicable.

\section{Competing interests}

Mohammad Z. Haider is a member of the BMC Pediatrics Editorial Board. Other authors declare that they have no competing interests.

\section{Publisher's Note}

Springer Nature remains neutral with regard to jurisdictional claims in published maps and institutional affiliations.

\section{Author details}

${ }^{1}$ Department of Pediatrics, Faculty of Medicine, Kuwait University, P.O. Box 24923, Safat-13110 Jabriya, Kuwait. ²Department of Pediatrics, Adan Hospital, Al-Adan, Kuwait. ${ }^{3}$ Department of Pediatrics, Farwania Hospital, Farwania, Kuwait. ${ }^{4}$ Family Medicine and Pediatric Unit, Dasman Diabetes Institute, Dasman, Kuwait. ${ }^{5}$ Medical Laboratories, Mubarak Al-Kabeer Hospital, Jabriya, Kuwait.

Received: 31 October 2018 Accepted: 1 March 2019

Published online: 07 March 2019

\section{References}

1. Shaltout AA, Wake D, Thanaraj TA, Omar DM, Al-AbdulRazzaq D, Channanath A, et al. Incidence of type-1 diabetes has doubled in Kuwaiti children 0-14 years over the last 20 years. Ped Diabetes. 2017;18(8):761-6.

2. Taha TH, Moussa MA, Rashid AR, Fenech FF. Diabetes mellitus in Kuwait. Incidence in the first 29 years of life. Diabetologia. 1983;25(4):306-8.

3. Karvonen M, Viik-Kajander M, Moltchanova E, Libman I, LaPorte R, Tuomilehto J. Incidence of childhood type 1 diabetes worldwide. Diabetes Care. 2000;23(10):1516-26.

4. Bener A, Al-Ali M, Hoffmann GF. High prevalence of vitamin D deficiency in young children in a highly sunny humid country: a global health problem. Minerva Pediatr. 2009;61(1):15-22.

5. Gordon CM, Feldman HA, Sinclair L, Williams AL, Kleinman PK, PerezRossello J, Cox JE. Prevalence of vitamin D deficiency among healthy infants and toddlers. Arch Pediatr Adolesc Med. 2008;162(6):505-12.

6. Jabbar Z, Aggarwal PK, Chandel N, Kohli HS, Gupta KL, Sakhuja V, Jha V. High prevalence of vitamin D deficiency in north Indian adults is exacerbated in those with chronic kidney disease. Nephrology. 2009;14(3):345-9.

7. Rovner AJ, O'Brien KO. Hypovitaminosis D among healthy children in United States: a review of the current evidence. Arch Pediatr Adolesc Med. 2008;162(6):513-9.

8. Rasoul MA, Al-Mahdi M, Al-Kandari H, Dhaunsi GS, Haider MZ. Low serum vitamin- D status is associated with high prevalence and early onset of type-1 diabetes mellitus in Kuwaiti children. BMC Pediatr. 2016;16:95. https://doi.org/10.1186/s12887-016-0629-3.

9. Lemire J. 1,25-Dihydrovitamin D3-a hormone with immunomodulatory properties. Z Rheumatol. 2000;59(Suppl 1):24-7.

10. Mathieu C, van Etten E, Decallonne B, Guilietti A, Gysemans C, Bouillon R, Overbergh L. Vitamin D and 1,25-dihydrovitamin D3 as modulators in the immune system. J Steroid Biochem Mol Biol. 2004;89-90(1-5):449-52.

11. Littorin B, Blom P, Scholin A, Arngvist HJ, Blohme G, Ekbom-Schnell A, et al. Lower levels of plasma 25-hydroxyvitamin D among young adults at 
diagnosis of autoimmune type 1 diabetes compared with control subjects: results from the nationwide diabetes incidence study in Sweden (DISS). Diabetologia. 2006;49(12):2847-52.

12. Pozzilli P, Manfrini S, Crino A, Picardi A, Leomanni C, Cherubini V, et al. Low levels of 25-hydroxyvitamin D3 and 1,25-dihydroxyvitamin D3 in patients with newly diagnosed type 1 diabetes. Horm Metab Res. 2005;37(11):680-3.

13. Nagpal S, Na S, Rathnachalam R. Noncalcemic actions of vitamin D receptor ligands. Endocr Rev. 2005;26:662-87.

14. Mathieu C, Waer M, Laureys J, Rutgeerts O, Bouillon R. Prevention of autoimmune diabetes in NOD mice by 1,25 dihydrovitamin D3. Diabetologia. 1994;37:552-8.

15. The EURODIAB. Sub-study 2 study group. Vitamin D supplement in early childhood and risk for type 1 (insulin-dependent) diabetes mellitus. Diabetologia. 1999;42:51-4.

16. Hypponen E, Laara E, Reunanen A, Jarvelin MR, Virtanen SM. Intake of vitamin $D$ and risk of type 1 diabetes: a birth-cohort study. Lancet. 2001;358:1500-3.

17. Fronczak CM, Baron AE, Chase HP, et al. In utero dietary exposures and risk of islet autoimmunity in children. Diabetes Care. 2003;26:3237-42

18. Lemos MC, Fagulha A, Coutinho E, Gomes L, Bastos M, Barros L, et al. Lack of association of vitamin $D$ receptor gene polymorphisms with susceptibility to diabetes mellitus in the Portuguese population. Hum Immunol. 2008:69:134-8.

19. Crofts LA, Hancock MS, Morrison NA, Eisman JA. Multiple promoters direct the tissue-specific expression of novel $\mathrm{N}$-terminal variant human vitamin $\mathrm{D}$ receptor transcripts. Proc Natl Acad Sci U S A. 1998;95:10529-34.

20. Walters MR. Newly identified actions of the vitamin D endocrine system. Endocr Rev. 1992;13:719-64.

21. Van Etten E, Verlinden L, Giulietti A, Ramos-Lopez E, Branisteanu DD, Ferreira $G B$, et al. The vitamin $D$ receptor gene Fokl polymorphism: functional impact on the immune system. Eur J Immunol. 2007:37:395-405.

22. McDermott MF, Ramachandran A, Ogunkolade BW, Aganna E, Curtis D, Boucher BJ, et al. Allelic variation in the vitamin D receptor influences susceptibility to IDDM in Indian Asians. Diabetologia. 1997;40:971-5.

23. Ban Y, Taniyama M, Yanagawa T, Yamada S, Maruyama T, Kasuga A, Ban Y. Vitamin D receptor initiation codon polymorphism influences genetic susceptibility to type 1 diabetes mellitus in the Japanese population. BMC Med Genet. 2001;2:7. https://doi.org/10.1186/1471-2350-2-7.

24. Mohammadnejad Z, Ghanbari M, Ganjali R, Afshari JT, Heydarpour M, Taghavi SM, et al. Association between vitamin D receptor gene polymorphisms and type 1 diabetes mellitus in Iranian population. Mol Biol Rep. 2012;39:831-7.

25. Turpeinen H, Hermann R, Vaara S, Laine AP, Simell O, Knip M, et al. Vitamin $D$ receptor polymorphisms: no association with type 1 diabetes mellitus in the Finnish population. Eur J Endocrinol. 2003;149:591-6.

26. Boraska V, Skrabic V, Zeggini E, Groves CJ, Buljubasic M, Peruzovic M, Zemunik T. Family-based analysis of vitamin D receptor gene polymorphisms and type 1 diabetes in population of South Croatia. J Hum Genet. 2008;53:210-4.

27. Angel B, Santos JL, Carrasco E, Albala C, Perez-Bravo F. Vitamin D receptor polymorphism and susceptibility to diabetes in Chilean subjects: a caseparent study. Eur J Epidemiol. 2004;19:1085-7.

28. Khalid KE. Vitamin D receptor gene polymorphisms in Sudanese children with type 1 diabetes. AIMS Genet. 2016;3(3):167-76.

29. Mukhtar M, Batool A, Wajid A, Qayyum I. Vitamin D receptor gene polymorphisms influence T1D susceptibility among Pakistanis. Int J Genomics. 2017. https://doi.org/10.1155/2017/4171254.

30. Xiao XH, Liu ZL, Wang H, Sun Q, Li WH, Yang GH, Liu QY. Effects of vitamin $D$ receptor gene polymorphisms on susceptibility to type 1 diabetes mellitus. Chinese Med Sci J. 2006;21:95-8.

31. Chang TJ, LeiHH YJI, Chiu KC, Lee KC, Chen MC, Tai TY, Chuang LM. Vitamin $D$ receptor gene polymorphisms influence susceptibility to type 1 diabetes mellitus in the Taiwanese population. Clin Endrocrinol. 2000;52:575-80.

32. Iyar A, Lanham-New S, Khoja S, Al-Ghamdi M, Al Doghaither H. Relationship between vitamin $\mathrm{D}$ receptor gene polymorphisms and type 1 diabetes mellitus in Saudi patients. Int J Pharmacol. 2017. https://doi.org/10.3923/ijp. 2017.1092.1097.

33. Cheon C-K, Nam H-K, Lee K-H, Kim SY, Song JS, Kim C. Vitamin D receptor gene polymorphisms and type 1 diabetes mellitus in a Korean population. Pediatr Int. 2015;57:870-4.
34. Marti G, Audi L, Esteban C, Oyarzabal M, Chueca M, Gussinye M, et al. Association of vitamin D receptor gene polymorphism with type 1 diabetes mellitus in two Spanish populations. Medicina Clinica. 2004;123:286-9.

35. Thorsen SU, Mortensen HB, Carstensen B, Fenger M, Thuesen BH, Husemoen L, et al. No association between type 1 diabetes and genetic variation in the vitamin D metabolism genes: a Danish study. Pediatr Diabetes. 2014;15:416-21.

36. Penna-Martinez M, Badenhoop K. Inherited variation in vitamin D genes and type 1 diabetes predisposition. Genes. 2017:8:125. https://doi.org/10.3390/ genes8040125.

37. Sahin OA, Goksen D, Ozpinar A, Serdar M, Onay H. Association of vitamin D receptor polymorphisms and type 1 diabetes susceptibility in children: a meta-analysis. Endocrine Connections. 2017;6:159-71.

38. Wang G, Zhang Q, Xu N, Xu K, Wang J, He W, Yang T. Association between two polymorphisms (Fokl and Bsml) of the vitamin D receptor gene and type 1 diabetes mellitus in Asian population: a meta-analysis. PLoS One. 2014:9(3):e89325.

39. Haider MZ, Rasoul MA, Al-Mahdi M, Al-Kandari H, Dhaunsi GS. Association of protein tyrosine phosphatase non-receptor type 22 gene functional variant C1858T, HLA-DQ/DR genotypes and autoantibodies with type-1 diabetes mellitus in Kuwaiti Arabs. PLoS One. 2018;13(6):e0198652 https://doi.org/10. 1371/journal.pone.0198652.

40. Craig ME, Jefferies C, Dabelea D, Balde N, Seth A, Donaghue KC. Definition, epidemiology, and classification of diabetes in children and adolescents. Pediatr Diabetes. 2014;15(Suppl 20):4-17.

41. Rojnic Putarek N, Ille J, Spehar Uroic A, Skrabic V, Stipancic G, et al. Incidence of type 1 diabetes mellitus in 0 to 14 -y-old children in Croatia - 2004 to 2012 study. Pediatr Diabetes. 2015;16:448-53.

42. Sambrook J, Fritsch EF, Maniatis T. Molecular Cloning - A Laboratory Manual, 2nd Ed. 1989. Cold Spring Harbor laboratory, New York, USA.

43. Panierakis C, Goulielmos G, Mamoulakis D, Petraki E, Papavasiliou E, Galanakis E. Vitamin D receptor gene polymorphisms and susceptibility to type 1 diabetes in Crete. Greece Clin Immunol. 2009;133:276-81.

44. Yavuz DG, Keskin L, Kiyici S, Sert M, Yazici D, Sahin I, et al. Vitamin D receptor gene Bsml, Fokl, Apal, Taql polymorphisms and bone mineral density in a group of Turkish type 1 diabetes patients. Acta Diabetol. 2011;48:329-36.

45. Dilmec F, Uzner E, Akkafa F, Kise E, van Kuilenburg ABP. Detection of VDR gene Apal and Taql polymorphisms in patients with type 2 diabetes mellitus using PCR-RFLP method in a Turkish population. J Diabetes \& Complications. 2010;24:186-91.

46. Jurutka PW, Remus GK, Whitfield PD, Thompson JC, Hsieh H, Zitzer P, et al. The polymorphic $\mathrm{N}$ terminus in human vitamin $\mathrm{D}$ receptor isoforms influences transcriptional activity by modulating interaction with transcription factor IIB. Mol Endocrinol. 2000;14:401-20.

47. Moran-Auth Y, Penna-Martinez M, Badenhoop K. VDR Fokl polymorphism is associated with a reduced T-helper cell population under vitamin D stimulation in type 1 diabetes patients. J Steroid Biochem Mol Biol. 2015:148:184-6.

48. Uitterlinden AG, Fang Y, Van Meurs JB, Pols HA, Van Leeuwen JP. Genetics and biology of vitamin D receptor polymorphisms. Gene. 2004;338:143-56.

49. Gross C, Eccleshall TR, Malloy PJ, Villa ML, Marcus R, Feldman D. The presence of a polymorphism at the translation initiation site of the vitamin $D$ receptor gene is associated with low bone mineral density in postmenopausal Mexican-American women. J Bone Miner Res. 1996;11:1850-5.

50. Haussler MR, Whitfield GK, Haussler CA, Hsieh JC, Thompson PD, Selznick $\mathrm{SH}$, et al. The nuclear vitamin D receptor: biological and molecular regulatory properties revealed. J Bone Miner Res. 1998;13:325-49.

51. Zemunik T, Skrabic V, Boraska V, Diklic D, Terzic IM, Capkun V, et al. Fokl polymorphism, vitamin D receptor, and Interleukin-1 receptor haplotypes are associated with type 1 diabetes in the Dalmatian population. J Mol Diagnostics. 2005;7:600-4.

52. Mory DB, Rocco ER, Miranda WL, Kasamatsu T, Crispim F, Dib SA. Prevalence of vitamin D receptor gene polymorphisms Fokl and Bsml in Brazilian individuals with type 1 diabetes and their relation to beta-cell autoimmunity and to remaining beta-cell function. Hum Immunol. 2009;70:447-51

53. Abd-Allah SH, Pasha HF, Hagrass HA, Alghobashy AA. Vitamin D status and vitamin $D$ receptor gene polymorphisms and susceptibility to type 1 diabetes in Egyptian children. Gene. 2014;536:430-4. 
54. Fassbender WJ, Goertz B, Weismuller K, Steinhauser B, Stracke H, Auch D, et al. VDR gene polymorphisms are overexpressed in German patients with type 1 diabetes compared to healthy controls without effect on biochemical parameters of bone metabolism. Horm Metab Res. 2002;34:330-7.

55. Pani MA, Knapp M, Donner H, Braun J, Baur MP, Usadel KH. Vitamin D receptor allele combinations influence genetic susceptibility to type 1 diabetes in Germans. Diabetes. 2000;49:504-7.

56. Ogunkolade BW, Boucher BJ, Prahl JM, Bustin SA, Burrin JM, Noonan K, et al. Vitamin $D$ receptor (VDR) mRNA and VDR protein levels in relation to vitamin D status, insulin secretory capacity, and VDR genotype in Bangladeshi Asians. Diabetes. 2002;51:2294-300.

57. Valdivielso JM, Fernandez E. Vitamin D receptor polymorphisms and disease. Clin Chim Acta. 2006;371:1-12.

58. Silva JD, Guimaraes RL, Brandao LAV, Arauja J, Segat L, Crovella S, et al. Vitamin D receptor (VDR) gene polymorphisms and age onset in type 1 diabetes mellitus. Autoimmunity. 2013;46(6):382-7.

59. Motohashi Y, Yamada S, Yanagawa T, Maruyama T, Suzuki R, Niino M, et al. Vitamin $D$ receptor gene polymorphism affects onset pattern of type 1 diabetes. J Clin Endocrinol Metab. 2003;88(7):3137-40.

60. Singh S, Singh UG, Agarwal NK, Singh RG, Kumar SB. Prevalence of autoantibodies and HLA DR, DQ in type 1 diabetes mellitus. J Clin Diagnostic Res. 2016;10(7):EC9-EC13. https://doi.org/10.7860/JCDR/2016/ 18657.8163.

61. Bingley PJ. Clinical applications of diabetes in antibody testing. J Clin Endocrinol Metab. 2010;95:25-33.

62. Ziegler AG, Nepom GT. Prediction and pathogenesis in type 1 diabetes. Immunity. 2010;32:468-78.

63. Wenzlau JM, Juhl K, Yu L, Moua O, Sarkar SA, Gottlieb P, et al. The cation efflux transporter ZnT8 (SIc30A8) is a major autoantigen in human type 1 diabetes. Proc Natl Acad Sci U S A. 2007;104:17040-5.

64. Verge CF, Stenger D, Bonifacio E, Colman PG, Pilcher C, Bingley PG, et al. Combined use of autoantibodies (IA-2ab), (GADAb, IAA, ICA) in type 1 diabetes: combinatorial islet autoantibody workshop. Diabetes. 1998:47:1857-66.

65. Manan H, Angham AM, Sitebanat A. Genetic and auto-antibody markers in Saudi children with type 1 diabetes. Hum Immunol. 2010;71:1238-42.

66. Chan JCN, Yeung VTF, Chow CC, Ko GTC, Mackey IR, Rowley MJ, et al. Pancreatic beta cell function and antibodies to glutamic acid decarboxylase (anti-GAD) in Chinese patients with clinical diagnosis of insulin-dependent diabetes mellitus. Diabetes Res Clin Pract. s1996;32:27-34.

Ready to submit your research? Choose BMC and benefit from:

- fast, convenient online submission

- thorough peer review by experienced researchers in your field

- rapid publication on acceptance

- support for research data, including large and complex data types

- gold Open Access which fosters wider collaboration and increased citations

- maximum visibility for your research: over $100 \mathrm{M}$ website views per year

At $\mathrm{BMC}$, research is always in progress.

Learn more biomedcentral.com/submissions 